\title{
The Effect of Training and Motivation on ASN Performance in the Protocol Section of the General Bureau of the Bengkulu Province Secretariat
}

\author{
Pengaruh Diklat dan Motivasi terhadap Kinerja ASN pada Bagian \\ Protokol Biro Umum Setda Provinsi Bengkulu \\ Harsen Jenizar 1); Karona Cahya Susena ${ }^{2) ;}$ Abdul Rahman²) \\ 1) Study Program of Management Faculty of Economic, Universitas Dehasen Bengkulu \\ 2) Department of Management, Faculty of Economic, Universitas Dehasen Bengkulu \\ Email: ${ }^{1)}$ harsenjenizar79@gmail.com; ${ }^{2)}$ karona.cs@unived.ac.id
}

How to Cite :

Jenizar, H., Susena, K. C., Rahman, A. (2021). The Effect of Training and Motivation on ASN Performance in the Protocol Section of the General Bureau of the Bengkulu Province Secretariat. JURNAL EMAK, 2(3). DOI: https://doi.org/10.53697/emak.v2i3

\section{ARTICLE HISTORY}

Received [1 Juni 2021]

Revised [10 Juni 2021]

Accepted [3 juli 2021]

KEYWORDS

Training and Motivation, ASN

Performance, Protoco

Section of the General Bureau This is an open access article under the $C C-B Y$-SA license

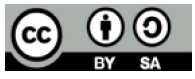

\section{ABSTRAK}

Tujuan penelitian ini adalah untuk mengetahui Pengaruh Diklat dan Motivasi terhadap Kinerja ASN pada Bagian Protokol Biro Umum Setda Provinsi Bengkulu. Penelitian ini menggunakan penelitian kuantitatif, penelitian kuantitatif adalah suatu proses menemukan pengetahuan yang menggunakan data berupa angka sebagai alat menganalisis keterangan mengenai apa yang ingin diketahui. Nilai koefisien determinasi atau $\mathrm{R}$ square adalah sebesar 0,677. Jadi besarnya nilai koefisien determinasi adalah 0,677 atau sama dengan $67,7 \%$ Angka tersebut mengandung arti bahwa variabel motivasi (XI) dan Kepemimpinan (X2) secara simultan (bersama-sama) berpengaruh terhadap variabel Kinerja (Y) sebesar 67,7\%. Sedangkan sisanya $(100 \%-67,7 \%=32,3 \%)$ dipengaruhi oleh variabel lain di luar persamaan regresi ini atau variabel yang tidak diteliti. Hal ini membuktikan pengaruh yang ditimbulkan motivasi dan kepemimpinan terhadap kinerja pada penelitian ini cukup besar.

\section{ABSTRACT}

The purpose of this study was to determine the effect of training and motivation on the performance of ASN in the Protocol Section of the General Bureau of the Bengkulu Province Secretariat. This study uses quantitative research, quantitative research is a process of finding knowledge that uses data in the form of numbers as a tool to analyze information about what you want to know. The value of the coefficient of determination or $R$ square is $\mathbf{0 . 6 7 7}$. So the value of the coefficient of determination is 0.677 or equal to $67.7 \%$ This number means that the motivation variable (XI) and leadership (X2) simultaneously (together) affect the performance variable $(Y)$ of $67.7 \%$. While the rest $(100 \%-67.7 \%$ $=32.3 \%$ ) is influenced by other variables outside this regression equation or variables not examined. This proves that the influence of motivation and leadership on performance in this study is quite large. 


\section{PENDAHULUAN}

Undang-Undang Republik Indonesia Nomor 5 Tahun 2014 Tentang Aparatur Sipil Negara menjelaskan bahwa Pegawai Aparatur Sipil Negara yang selanjutnya disebut Pegawai ASN adalah pegawai negeri sipil dan pegawai pemerintah dengan perjanjian kerja yang diangkat oleh pejabat pembina kepegawaian dan diserahi tugas dalam suatu jabatan pemerintahan atau diserahi tugas negara lainnya dan digaji berdasarkan peraturan perundang-undangan.

Kinerja dalam sebuah organisasi merupakan salah satu unsur yang tidak dapat dipisahkan dalam suatu lembaga organisasi, baik itu lembaga pemerintahan maupun lembaga swasta. Kinerja merupakan hasil kerja secara kualitas dan kuantitas yang dapat dicapai oleh seorang pegawai dalam melaksanakan tugas sesuai dengan tanggung jawab yang diberikan kepadanya Dalam menghadapi tantangan era global yang diwarnai dengan persaingan yang semakin ketat harus dipersiapkan sumber daya manusia yang tangguh serta berkualitas untuk mengantisipasi segala perubahan yang akan terjadi.

Setiap lembaga dalam melaksanakan berbagai aktivitasnya membutuhkan beberapa sumber daya, termasuk sumber daya manusia (SDM). Sumber daya manusia adalah salah satu asset yang sangat penting dalam lembaga, yang sekaligus juga merupakan mitra lembaga dalam menjalankan aktivitas lembaga karena mereka yang menghasilkan dan melaksanakan pekerjaan. Tuntutan perubahan perilaku aparatur pemerintahan yang tadinya cenderung ingin dilayani kepada perilaku yang memberikan pelayanan kepada masyarakat semakin mendesak. Menurut Suradinata (1996:4) untuk menghadapi tuntutan masyarakat tersebut maka manajemen pemerintahan harus lebih meningkatkan dan menggerakkan sumber daya manusia yang ada pada unit-unit organisasi pemerintah secara professional dalam memberi pelayanan.

Pentingnya kualitas sumber daya manusia tersebut karena peranannya sebagai motor penggerak yang dapat mempengaruhi kemampuan dan keberhasilan pencapaian tujuan organisasi secara efektif dan efisien. Pengembangan sumber daya manusia merupakan suatu condition sine qua non, atau sesuatu yang tidak dapat dihindarkan yang harus terus dilakukan, karena bagaimanapun canggihnya sarana dan prasarana organisasi tanpa ditunjang oleh sumber daya manusia yang berkualitas itu tidak dapat maju dan berkembang sehubungan dengan peranan manusia yang sangat penting dan strategis dalam organisasi termasuk pemerintah daerah sangat perlu dalam pengembangan sumber daya manusia, karena sumber daya manusia merupakan faktor produksi langsung terpenting dalam organisasi pemerintah daerah.

Pegawai ASN sebagai unsur utama sumber daya manusia memiliki peranan penting dalam menentukan keberhasilan penyelenggaraan pemerintahan dan pembangunan. Sosok Pegawai ASN yang mampu memainkan peranan tersebut adalah Pegawai ASN yang memiliki kompetensi yang diindikasikan dari sikap dan perilakunya yang penuh dengan kesetiaan dan ketaatan kepada negara, bermoral dan bermental baik, profesional, sadar akan tanggung jawab sebagai pelayan publik, serta mampu menjadi perekat persatuan dan kesatuan bangsa.Oleh karena itu, masyarakat memiliki ekspektasi yang tinggi terhadap ASN agar memberikan kinerja yang maksimal.Namun saat ini masih terdapat beberapa masalah yang membuat kinerja ASN di Indonesia tidak maksimal, termasuk adanya tindakan oknum-oknum yang tidak bertanggung jawab, seperti penyalahgunaan wewenang, tindakan indisipliner, tindak pidana korupsi, perselingkuhan dan sebagainya yang tentunya melanggar ketentuan yang telah ditetapkan

Berdasarkan informasi yang dikutip dari situs http://ruanghati.com(diunduh pada tanggal 2 Februari 2021, pukul 20.17 WIB), yang menyatakan, berdasarkan data dari Kementerian Pemberdayaan Aparatur Negara dan Reformasi Birokrasi memperkirakan 40 persen dari 4,7 juta pegawai ASN di Indonesia memiliki kinerja buruk dan akan diminta menjalani pensiun dini. Sementara berdasarkan data Badan Pertimbangan Kepegawaian (BAPEK), di tahun 2021 terdapat 77 kasus pelanggaran PNS yang disidangkan, Dari 77 kasus dalam sidang BAPEK, sebanyak 37 diperingan, 31 kasus diperkuat, ada 6 yang dibatalkan, 2 kasus dipending, dan satu kasus dalam pertimbangan BAPEK tentang tindakan atas putusan kasasi yg belum ada keputusan, sedangkan 
dari sidang tersebut 30 ASN diberhentikan tidak hormat. Pelanggaran yang dilakukan ASN berdasarkan data BAPEK tersebut diantaranya, pembunuhan berencana, tidak masuk kerja, narkoba, melakukan korupsi, menjadi isteri kedua, beristeri lebih dari satu tanpa ijin atasan, pemalsuan SK kenaikan gaji berkala, selingkuh, kumpul kebo, dan penggelapan dana. Dengan adanya kasus tersebut, tentunya perlu adanya penerapan kedisiplinan dan sanksi terhadap ASN yang melanggar peraturan terutama tindakan tegas dari instansi terkait.Selain itu perlu adanya system penilaian kinerja pegawai.

Meningkatkan kinerja juga dapat dilakukan dengan pembentukan sikap dan perilaku yang diwujudkan melalui Diklat. Diklat sendiri memegang peranan penting dalam pembentukan sikap dan perilaku calon Pegawai Negeri Sipil ini. Hal ini didasarkan dari tujuan Pendidikan dan Pelatihan bagi ASN ini yaitu, menumbuhkan sikap dan semangat pengabdian yang berorientasi pada kepentingan masyarakat, bangsa, negara, dan tanah air, kemudian meningkatkan kompetensi teknis, manajerial, dan/atau kepemimpinannya serta meningkatkan efisiensi, efektifitas dan kualitas pelaksanaan tugas yang dilakukan dengan semangat kerjasama dan tanggung jawab sesuai dengan lingkungan kerja dan organisasinya. Dalam Peraturan Pemerintah No. 101 Tahun 2000, diklat prajabatan (golongan I, II, dan III) bertujuan untuk, pertama, meningkatkan pengetahuan, keahlian, keterampilan dan sikap untuk dapat melaksanakan tugas secara profesional dengan dilandasi kepribadian dan etika Pegawai ASN sesuai dengan kebutuhan instansi, kedua, menciptakan aparatur yang mampu berperan sebagai pembaharu dan perekat persatuan dan kesatuan bangsa, ketiga, memantapkan sikap dan semangat pengabdian yang berorientasi pada pelayanan, pengayoman, dan pemberdayaan masyarakat, keempat, menciptakan kesamaan visi dan dinamika pola pikir dalam melaksanakan tugas pemerintahan umum dan pembangunan demi terwujudnya kepemerintahan yang baik.

Aspek pendidikan dan pelatihan semakin penting dan mendesak dalam peningkatan kualitas aparat atau pegawai agar mempunyai kemampuan manajerial dan teknis fungsional untuk mempengaruhi efektivitas pelayanan publik yang sangat diliputi dengan berbagai penyakit birokrasi, kinerja yang rendah, menurunnya produktivitas dan mutu serta kompleksitas masalah pembangunan yang semakin meningkat.

Selain program Diklat, motivasi kerja sebagai aspek psikologis individu pegawai merupakan faktor lain yang dapat meningkatkan kinerja pegawai, karena lembaga bukan saja mengharapkan pegawai yang mampu, cakap dan terampil, tetapi yang penting mereka mau bekerja dengan giat dan mempunyai keinginan untuk mencapai hasil yang maksimal, sebab kemampuan, kecakapan dan keterampilan tidak ada artinya jika mereka tidak mau bekerja keras. Kenyataan memperlihatkan bahwa pelayanan publik belum efektif dan efisien karena latar belakang pendidikan dan pelatihan serta motivasi kerja yang dimiliki aparat belum sepenuhnya mendukung pelaksanaan tugas atau belum melaksanakan fungsi pelayanan secara baik. Hal ini menyebabkan prospek pelayanan publik cenderung tidak efektif dan efisien yang lebih jauh membawa dampak bagi penyelenggaraan pemerintah dan pelaksanaan pembangunan. Berbagai masalah yang muncul berkaitan dengan efektivitas pelayanan publik menunjukan bahwa aspek pendidikan dan pelatihan serta motivasi kerja sebagai faktor penunjang bagi aparat atau pegawai dalam melaksanakan setiap tugasnya, masih belum mendapat perhatian yang serius dari pemerintah.

Berdasarkan uraian itu, maka dalam pengembangan organisasi pemerintah saat ini adalah upaya peningkatan kualitas sumber daya manusianya (aparat atau pegawai) melalui proses pendidikan dan pelatihan yang lebih diarahkan pada pembentukan pribadi aparat, pembentukan dan penanaman nilai di dalam diri aparat yang berlangsung dalam masyarakat, sehingga pada akhirnya, melalui pelaksanaan tugas setiap aparat akan dapat meningkatkan pelayanan kepada masyarakat. Dengan demikian, pelaksanaan suatu tugas tanpa didukung dengan latar belakang pendidikan dan motivasi kerja akan mengurangi upaya pencapaian pelayanan secara efektif dan efisien.

Dengan diadakannya program pendidikan dan pelatihan maka diharapkan pegawai lebih mempunyai keterampilan, pengetahuan serta wawasan dalam pelayanan sehingga dapat 
meningkatkan motivasi kerja mereka yang akhirnya akan meningkatkan pula prestasi kerja. Pada lembaga pemerintahan daerah bagian dari unit kerja Biro Umum Sekretariat Daerah Provinsi Bengkulu, aparatur sipil Negara Bagian Keprotokolan memiliki peran penting dalam mengatur suatu acara dan melaksanakan rekapitulasi kegiatan pimpinan.

Keprotokolan mengatur kegiatan pimpinan mulai dari persiapan pelaksanan sampai acara selesai dengan sebaik mungkin. Namun banyak kemungkinan yang akan terjadi dalam suatu pelaksanaan kegiatan atau acara. Hal-hal yang terjadi di lapangan terkadang tidak sesuai denga rencana yang sudah di persiapkan. Hal ini menuntut agar setiap pegawai keprotokoleran memiliki kinerja yang baik dalam pekerjaannya. Seperti sikap disiplin, tanggung jawab, cerdas, peka terhadap situasi dan integritas dari masing masing pegawai keprotokolan yang baik dalam melaksankan tugas. Sikap disiplin, tanggung jawab, peka terhadap situasi dan integritas dari masing masing pegawai keprotokolan dalam melaksankan tugas dapat di tingkatkan dengan pelatihan pelatihan yang bisa membantu meningkatkan kinerja para pegawai salah satu nya dengan melakukan diklat dan mengadakan kegiatan kegiatan yang memotivasi. Pelaksanaan diklat dan motivasi dirasa memiliki pengaruh terhadap kinerja ASN pada bagian keprotokolan sehingga diharapkan mampu melaksankan kinerja lebih baik.

\section{LANDASAN TEORI}

\section{Pendidikan dan Pelatihan (Diklat), Motivasi, Kinerja}

Pendidikan dan pelatihan adalah merupakan upaya untuk mengembangkan sumber daya aparatur, terutama untuk peningkatan profesionalime yang berkaitan dengan, keterampilan administrasi dan keterampilan manajemen (kepemimpinan). Sebagaimana yang dikemukakan oleh Notoatmodjo (2010:4), bahwa untuk meningkatkan kualitas kemampuan yang menyangkut kemampuan kerja, berpikir dan keterampilan maka pendidikan dan pelatihan yang paling penting diperlukan. Menurut Ranupandojo dan Husman (2011:4) pendidikan merupakan usaha kegiatan untuk meningkatkan pengetahuan umum seseorang termasuk di dalamnya teori untuk memutuskan persoalan persoalan yang menyangkut kegiatan pencapaian tujuan. Sedangkan latihan merupakan kegiatan untuk memperbaiki kemampuan kerja melalui pengetahuan praktis dan penerapannya dalam usaha pencapaian tujuan.

Istilah motivasi berasal dari kata Latin "movere" yang berarti dorongan atau menggerakkan. Motivasi mempersoalkan bagaimana cara mengarahkan daya dan potensi agar bekerja mencapai tujuan yang ditentukan (Malayu S.P Hasibuan, 2006: 141). Pada dasarnya seorang bekerja karena keinginan memenuhi kebutuhan hidupnya. Dorongan keinginan pada diri seseorang dengan orang yang lain berbeda sehingga perilaku manusia cenderung beragam di dalam bekerja. Menurut Wibowo (2011:379) motivasi merupakan dorongan terhadap serangkaian proses perilaku manusia pada pencapaian tujuan. Sedangkan elemen yang terkandung dalam motivasi meliputi unsur membangkitkan, mengarahkan, menjaga, menunjukan intensitas, bersifat terus-menerus dan adanya tujuan

Kinerja berasal dari istilah Job performance atau actual performance (prestasi kerja atau prestasi sesungguhnya), atau juga hasil kerja secara kualitas atau kuantitas yang ingin dicapai oleh seorang pegawai dalam melaksanakan tugasnya sesuai dengan tanggung jawab yang diberikan kepadanya (Mangkunegara, 2007:67). Menurut Amstrong dan Baron (1998) dalam Wibowo (2011:2) Kinerja merupakan hasil pekerjaan yang mempunyai hubungan kuat dengan tujuan Strategi Organisasi kepuasan konsumen dan memberikan kontribusi ekonomi. Sedangkan menurut Sedarmayanti (2007:260) Kinerja adalah hasil kerja yang dapat dicapai seseorang atau sekelompok orang dalam suatu organisasi, sesuai dengan wewenang dan tanggung jawab masing-masing dalam upaya mencapai tujuan organisasi bersangkutan secara legal, tidak melangggar hukum dan sesuai dengan moral maupun etika. 


\section{METODE PENELITIAN}

Penelitian ini menggunakan penelitian kuantitatif, penelitian kuantitatif adalah suatu proses menemukan pengetahuan yang menggunakan data berupa angka sebagai alat menganalisis keterangan mengenai apa yang ingin diketahui. Menurut ( V. Wiratna Sujarweni dalam Metodologi Penelitian 2014 :39) penelitian kuantitatif menghasilkan penemuan-penemuan yang dapat dicapai menggunakan prosedur-prosedurstatistik atau cara-cara lain dari kuantifikasi (pengukuran).

Analisis regresi berganda digunakan oleh peneliti meramalkan bagaimana keadaan naik turunnya variabel independen, bila dua atau lebih variabel independen minimal dua.

Persamaan Regresi Liniear Berganda:

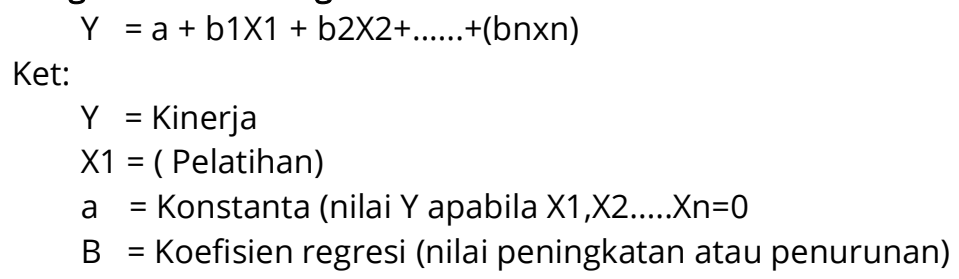

\section{HASIL DAN PEMBAHASAN}

\section{Hasil dan Pembahasan}

Berikut ini adalah hasil dari analisis regresi linear berganda pada penelitian ini. Tabel 1. Ringkasan Analisis Regresi Linear Berganda

\begin{tabular}{|l|c|c|c|}
\hline \multicolumn{1}{|c|}{ Variabel } & $\begin{array}{c}\text { Koefisien } \\
\text { Regresi }\end{array}$ & $\mathrm{t}_{\text {hitung }}$ & Sig \\
\hline Konstanta & 7,888 & & \\
\hline Motivasi (X1) & 0,162 & 1,640 & 0,108 \\
\hline Kepemimpinan (X2) & 0,660 & 5,700 & 0,000 \\
\hline F hitung $=48,243$ & & \\
\hline R Square $=0,677$ & & \\
\hline
\end{tabular}

(Sumber: Pengolahan Hasil Penelitian, 2020)

Dari hasil ringkasan output analisis regresi linear berganda di atas di dapat hasil dalam persamaan yang sudah dibahas sebelumnya di bab 3 yaitu

$\mathrm{Y}=<+\mathrm{b} 1 \mathrm{X} 1+\mathrm{b} 2 \mathrm{X} 2$

$Y=7,888+(0,162) X 1+(0,660) X 2$

Keterangan :

$\mathrm{Y}=$ Kinerja

$\mathrm{a}=$ Konstanta

X1 - Motivasi

$\mathrm{X} 2$ = Kepemimpinan

by $=$ koefisien Regresi Motivasi

b2 = koefisien Regresi Kepemimpinan

Dilihat dari koefisien regresi di atas motivasi dan kepemimpinan memiliki nilai koefisien regresi positif hal ini berarti pengaruh motivasi dan kepemimpinan terhadap kinerja memiliki pengaruh positif.

Untuk menguji hipotesis pada penelitian ini digunakan uji partial (t), Uji Simultan (f) dan Koefisien Determinasi ( $r$ ?).

1) Uji partial (uji-t) 
Uji partial (uji-t) digunakan untuk menguji apakah setiap variabel independent yaitu kepemimpinan (Xi) dan motivasi (X2) mempunyai pengaruh yang positif dan signifikan terhadap variabel dependent yaitu kinerja $(\mathrm{Y})$ secara parsial.

Tabel 2. Analisis regresi linear berganda

\begin{tabular}{|c|c|c|c|c|c|c|}
\hline & \multirow{2}{*}{ Model } & \multicolumn{2}{|c|}{$\begin{array}{c}\text { Unstandardized } \\
\text { Coefficients }\end{array}$} & \multirow{2}{*}{$\begin{array}{c}\begin{array}{c}\text { Standardized } \\
\text { Coefficients }\end{array} \\
\text { Beta }\end{array}$} & \multirow{2}{*}{$\mathrm{t}$} & \multirow{2}{*}{ Sig. } \\
\hline & & B & $\begin{array}{l}\text { Std. } \\
\text { Error }\end{array}$ & & & \\
\hline \multirow[t]{3}{*}{1} & (Constant) & 7.888 & 3.725 & & 2.118 & .040 \\
\hline & Motivasi (X1) & 162 & 099 & 194 & 1.640 & 108 \\
\hline & Kepemimpinan (X2) & 660 & .116 & 674 & 5.700 & 000 \\
\hline
\end{tabular}

a. Dependent Variable: Kinerja (Y)

(Sumber: Pengolahan Hasil Penelitian, 2021)

a. Uji-t pada pengaruh Motivasi terhadap Kinerja

Berdasarkan tabel output di atas diketahui nilai signifikansi (Sig) variabel Motivasi (X1) adalah sebesar 0,108. Karena nilai sig. 0,108 > probabilitas 0,05, maka dapat disimpulkan bahwa $\mathrm{HI}$ ditolak. Artinya tidak ada pengaruh Motivasi (X1) terhadap Kinerja (Y). selain itu dapat pula dilihat dari perbandingan antara nilai t hitung dengan $t$ tabel. Dari hasil output di atas t hitung bernilai 1,640 sedangkan t tabel untuk residu 46 adalah 2,013 sehingga t hitung $<$ t tabel. Maka hasil dari pengujian adalah dapat dilihat melalui tabel di bawah ini Tabel 3. Uji Hipotesis pengaruh Motivasi

\begin{tabular}{|l|c|l|}
\hline \multicolumn{1}{|c|}{ Uji-t } & Nilai & \multicolumn{1}{|c|}{ Hipotesis } \\
\hline$t_{\text {hitung }}$ & 1,640 & $\begin{array}{l}\text { Ho diterima dan Hi ditolak sehingga dapat } \\
\text { disimpulkan bahwa Motivasi tidak mempengaruhi } \\
\text { kinerja }\end{array}$ \\
\hline$t_{\text {tabel }}$ & 2,013 & \\
\hline
\end{tabular}

b. Uji-t pada pengaruh Kepemimpinan terhadap kinerja

Berdasarkan tabel output di atas diketahui nilai signifikansi (Sig) Motivasi Kerja(X2) adalah sebesar 0,000. Karena nilai sig. 0,000 <probabilitas 0,05, maka dapat disimpulkan bahwa HO ditolak. Artinya ada pengaruh kepemimpinan (X2) terhadap Kinerja (Y). selain itu dapat pula dilihat dari perbandingan antara nilai t hitung dengan $t$ tabel. Dari hasil output di atas t hitung bernilai 5,700 sedangkan t tabel untuk residu 46 adalah 2,013 sehingga t hitung $>\mathrm{t}$ tabel. Maka hasil dari pengujian adalah dapat dilihat melalui tabel di bawah ini.

Tabel 4. Uji Hipotesis pengaruh Kepemimpinan

\begin{tabular}{|c|c|l|}
\hline Uji-t & Nilai & \multicolumn{1}{|c|}{ Hipotesis } \\
\hline$t_{\text {thitung }}$ & 5,700 & $\begin{array}{l}\text { Ho ditolak dan Hi diterima sehingga dapat } \\
\text { disimpulkan bahwa kepemimpinan mempengaruhi } \\
\text { kinerja pegawai }\end{array}$ \\
\hline tabel & 2,013 & \\
\hline
\end{tabular}

(Sumber: Pengolahan Hasil Penelitian, 2021)

Berdasarkan tabel di atas, hasil thitung lebih besar dari trabel $(5,700>2,013)$ artinya Kepemimpinan memengaruhi kinerja pegawai.

2) Uji Simultan $F$

Uji simultan $\mathrm{f}$ dilakukan setelah melakukan uji t pada regresi linear berganda. Berikut hasil pengujian yang dilakukan dapat dilihat pada tabel ANOVA di bawah ini

Tabel 5. Uji Simultan $f$

\begin{tabular}{|c|c|c|c|c|c|}
\hline \multicolumn{7}{|c|}{ ANOVA $^{a}$} \\
\hline Model & $\begin{array}{c}\text { Sum of } \\
\text { squares }\end{array}$ & df & Mean Square & $F$ & Sig. \\
\hline
\end{tabular}




\begin{tabular}{|c|c|c|c|c|c|c|}
\hline 1 & Regression & 703.943 & 2 & 351.972 & 48.243 & $.000^{\mathrm{b}}$ \\
\cline { 2 - 7 } & Residual & 335.608 & 46 & 7.296 & & \\
\cline { 2 - 8 } & Total & 1039.551 & 48 & & & \\
\hline
\end{tabular}

a. Dependent Variable: Kinerja (V)

b. Predictors: (Constant), Kepemimpinan (X2), Motivasi (X1)

(Sumber: Pengolahan Hasil Penelitian, 2021)

Berdasarkan tabel output di atas, diketahui nilai sig. adalah sebesar 0,000. Karena nilai sig. $0,000<0,05$, maka sesuai dengan dasar pengambilan keputusan dalam uji $f$ dapat disimpulkan bahwa hipotesis diterima atau dengan kata lain motivasi (X1) dan Kepemimpinan (X2) secara simultan berpengaruh terhadap kinerja ( $\mathrm{Y}$ ). Jika melakukan uji $f$ dengan membandingkan $f$ hitung dengan $\mathrm{f}$ tabel berdasarkan output di atas didapatkan nilai $\mathrm{f}$ hitung sebesar 48,243 . Karena nilai $F$ hitung 48,243 > F table 3,20, maka sebagaimana dasar pengambilan keputusan dalam uji $F$ dapat disimpulkan bahwa hipotesis ke-3, HI diterima dan HO ditolak atau dengan kata lain Motivasi (X1) dan Kepemimpinan (X2) secara simultan (bersama-sama) berpengaruh terhadap Kinerja ( $\mathrm{Y}$ ).

\section{3) Uji Koefisien Determinasi ( $r$ )}

Sebelumnya peneliti telah melakukan uji Simultan $F$ untuk mengetahui pengaruh dari variabel motivasi (XI) dan Kepemimpinan (X2) terhadap Kinerja (Y). Maka kali ini akan dilakukan uji Determinasi untuk mengetahui persentase pengaruh dari variabel tersebut. uji koefisien determinasi $\left(r^{2}\right)$ dapat dilihat dari tabel output di bawah ini.

Tabel 6. Uji Koefisien Determinasi $\left(r^{2}\right)$

\begin{tabular}{|l|c|c|c|c|}
\hline \multicolumn{1}{|c|}{ Model } & $\mathrm{R}$ & $\begin{array}{c}\mathrm{R} \\
\text { Square }\end{array}$ & $\begin{array}{c}\text { Adjusted } \\
\text { Square }\end{array}$ & $\begin{array}{c}\text { Std. Error } \\
\text { of The } \\
\text { Estimate }\end{array}$ \\
\hline 1 & $823^{\mathrm{a}}$ & .677 & .663 & 2701 \\
\hline
\end{tabular}

a. Predictors: (Constant), Kepemimpinan (X2), Motivasi (X1)

(Sumber: Pengolahan Hasil Penelitian, 2021)

Berdasarkan tabel output di atas, diketahui nilai koefisien determinasi atau R square adalah sebesar 0,677. Jadi besarnya nilai koefisien determinasi adalah 0,677 atau sama dengan 67,7\% Angka tersebut mengandung arti bahwa variabel motivasi (XI) dan Kepemimpinan (X2) secara simultan (bersama-sama) berpengaruh terhadap variabel Kinerja $(Y)$ sebesar 67,7\%. Sedangkan sisanya $(100 \%-67,7 \%=32,3 \%)$ dipengaruhi oleh variabel lain di luar persamaan regresi ini atau variabel yang tidak diteliti. Hal ini membuktikan pengaruh yang ditimbulkan motivasi dan kepemimpinan terhadap kinerja pada penelitian ini cukup besar.

\section{Pembahasan}

Pada penelitian ini responden yang digunakan adalah para pegawai dari Bagian Protokol Biro Umum Setda Provinsi Bengkulu dengan jumlah pegawai sebanyak 49 orang. Para responden tersebut didominasi oleh jenis kelamin perempuan dengan rentang usia 24-44 tahun. Hampir seluruh responden memiliki pendidikan terakhir sarjana dengan lama bekerja lebih dari 10 tahun. Hasil penelitian tentang pendapat responden dalam pengisian Angket baik dalam variabel Motivasi, Kepemimpinan maupun Kinerja secara umum sudah menunjukkan hasil yang sangat baik. Hal ini dilihat dari besarnya nilai rata-rata skala perhitungan di setiap indikator pada masing-masing variabel. Pada umumnya setiap variabel menghasilkan rata-rata penilaian sangat baik.

Pada setiap inidikator pun skala perhitungan yang dihasilkan juga sangat tinggi. Hal ini berarti para pegawai di Bagian Protokol Biro Umum Setda Provinsi Bengkulu lebih menyukai dan 
lebih mengapresiasi motivasi yang diberikan serta kepenimpinan yang baik di Bagian Protokol Biro Umum Setda Provinsi Bengkulu.

Motivasi merupakan salah satu hal yang sangat penting pada proses berjalannya organisasi kedinasan di Bagian Protokol Biro Umum Setda Provinsi Bengkulu. Pada penelitian ini motivasi memiliki indikator antara lain Hubungan dengan rekan kerja dan atasan, Lingkungan Kerja, Kesempatan meningkatkan Pengetahuan dan keteramilan serta Pemberian Tunjangan. Diantara indicator tersebut yang memiliki hasil skala perhitungan tertinggi adalah Lingkungan kerja dengan pernyataan lingkungan kerja sangat bersih yang berdampak terhadap semangat dalam bekerja di Bagian Protokol Biro Umum Setda Provinsi Bengkulu. Selain itu pada variabel motivasi yang memiliki skala perhitungan tertinggi juga ditemukan di pernyataan hubungan harmonis terjalin antara pegawai di Bagian Protokol Biro Umum Setda Provinsi Bengkulu.

Pada variabel Kinerja hampir seluruh indikator menghasilkan nilai skala perhitungan yang sangat tinggi. Nilai skala tertinggi dihasilkan pada pernyataan "Saya merasa senang jika dapat mencapai target yang ditetapkan kantor/SKPD". Hal ini berarti para pegawai juga merasa senang jika target yang telah ditetapkan tercapai di Bagian Protokol Biro Umum Setda Provinsi Bengkulu Hampir seluruh indikator untuk variabel kinerja menghasilkan skala perhitungan sangat tinggi yang menghasilkan predikat rentang yang sangat baik. Berdasarkan hasil uji statistik dengan program statistik SPSS 25 menggunakan uji pada angket dan hasil angket yang telah disebarkan kepada 49 responden di Dinas Pengendalian Penduduk, Keluarga Berencana, Pemberdayaan Perempuan Dan Perlindungan Anak Provinsi Bengkulu pada dua variabel bebas yaitu motivasi dan Kepeinimpinan serta satu variabel terikat yaitu kinerja pegawai didapat hasil analisis sebagai berikut:

1. Angket yang di uji dengan uji Validitas menunjukkan hasil $r$ hitung $>$ tabel. Sehingga seluruh itein pada intrumen angket menunjukkan hasil yang valid. Hal ini dapat dilihat pada tabel 6 di atas.

2. Uji kedua yang dilakukan terhadap angket adalah uji reliabilitas, uji ini menghasilkan hasil instrument yang konsisten bagi jawaban yang diberikan oleh seseorang. Hal ini ditunjukkan dengan nilai cronbach's Alpha $>0,60$ dapat dilihat pada tabel 7 di atas.

3. Uji normalitas dilakukan untuk mengetahui apakah data yang di dapat sudah normal. Pada perhitungan di atas di dapat bahwa nilai signifikansi Asymp Sig (2-tailed) sebesar 0.200 lebih besar dari 0,05. Maka sesuai dengan pengambilan keputusan dalam uji normalitas Kolmogorov-Smimov, dapat disimpulkan bahwa data berdistribusi normal seperti ditunjukkan pada tabel 8 di atas.

4. Berdasarkan tabel 9 di atas, pada bagian Colinearity Statistics diketahui nilai Tolerance untuk variabel Motivasi (XI) dan Kepemimpinan (X2) adalah 0,501 lebih besar dari 0,10. Sementara, nilai VIF untuk variable Motivasi (XI) dan Kepemimpinan (X2) adalah 1,994 < 10,00. Maka dapat disimpulkan bahwa tidak terjadi gejala multikolineritas dalam model regresi pada penelitian ini.

5. Pada uji heteroskedastis pada tabel 10 , karena nilai signifikansi kedua variabel lebih besar dari 0,05 maka dapat disimpulkan bahwa tidak terjadi gejala heteroskedastisitas dalam model regresi pada penelitian ini.

6. Uji regresi lincar berganda digunakan bagi penelitian yang menggunakan dua variabel independen, pada penelitian ini yaitu motivasi dan kepemimpinan. Hasil analisis regresi linear berganda pada penelitian ini dapat dilihat pada tabel 11. Setelah melakukan pengujian kita dapat inelakukan uji selanjutnya yaitu ujit, uji $f$ dan uji determinasi.

a. Uji t dilakukan untuk menguji hipotesis tiap variabel, pada variable motivasi terhadap kinerja di dapat data analisis t hitung bernilai 1,640 sedangkan t tabel untuk residu 46 adalah 2,013 sehingga $t$ hitung $<\mathrm{t}$ tabel hal ini berarti motivasi tidak berpengaruh ternadap kinerja. Sedangkan pada Motivasi Kerjadidapat hasil t hitung bernilai 5,700 sedangkan $\mathrm{t}$ tabel untuk residu 46 adalah 2,013 sehingga $\mathrm{t}$ hitung $>\mathrm{t}$ tabel yang berarti kepemimpinan berpengarauh terbadap kinerja pegawai 
b. Uji $f$ dilakukan untuk inenguji hipotesis pengaruh antara motivasi dan kepemimpinan terhadap kinerja. Pada tabel 15 di dapat $F$ hitung 48,243 > F tabel 3,20, maka sebagaimana dasar pengambilan keputusan dalam uji $\mathrm{F}$ dapat disimpulkan bahwa hipotesis ke-3, HI diterima dan HO ditolak atau dengan kata lain Motivasi (XI) dan Kepemimpinan (X2) secara simultan (bersama-sama) berpengaruh terhadap Kinerja (Y).

c. Setelah mengetahui bahwa motivasi dan kepemimpinan berpengaruh secara simultan terhadap kinerja maka selanjutnya adalah melakukan uji determinasi untuk mencari nilai persentase dari pengaruh tersebut. Berdasarkan uji yang telah dilakukan didapatkan nilai koefisien determinasi atau $\mathrm{R}$ square adalah sebesar 0,677 . Jadi besarnya nilai koefisien determinasi adalah 0,677 atau sama dengan $67,7 \%$. Semakin mendekati 1 nilai dari $r$ square hal ini berarti persentase pengaruh semakin lemah dan sebaliknya.

\section{KESIMPULAN DAN SARAN}

\section{Kesimpulan}

Hasil analisis yang didapat dari penelitian ini terdapat tiga hal yaitu yang pertama terdapat pengaruh antara kepemimpinan dengan kinerja, artinya terdapat dampak yang ditimbulkan oleh kepemimpinan dalam sebuah organisasi terhadap kinerja pegawai di Bagian Protokol Biro Umum Setda Provinsi Bengkulu. Sedangkan motivasi tidak memiliki dampak apapun terhadap kinerja pegawai di Bagian Protokol Biro Umum Setda Provinsi Bengkulu, hal ini kemungkinan dikarenakan kurangnya motivasi diberikan pemerintah Provinsi Bengkulu seperti salah satunya tunjangan disebabkan masih rendahnya pendapatan asli daerah (PAD) yang menjadi sumber kas daerah selain dari bantuan pemerintah pusat.

\section{Saran}

Semakin terjalinnya kinerja antara pemimpin dan bawahannya, sehingga tampak pengaruh antara kepemimpinan dengan kinerja, artinya terdapat dampak yang ditimbulkan oleh kepemimpinan dalam sebuah organisasi terhadap kinerja pegawai di Bagian Protokol Biro Umum Setda Provinsi Bengkulu.

\section{DAFTAR PUSTAKA}

Iskandar. 2008. Metodologi Penelitian Pendidikan Dan Sosial Kuantitatif Dan Kualitatif Jakarta: Gaung Persada Press.

Peraturan Gubernur Bengkulu Nomor 39 Tahun 2016 Tentang Kedudukan, Susunan Organisasi, Tugas dan Fungsi, serta Tata Kerja Sekretariat Daerah Provinsi Bengkulu.

Peraturan Menteri Dalam Negeri Nomor 52 Tahun 2011 Tentang Standar Operasional Prosedur Di Lingkungan Pemerintah Provinsi Kabupaten/Kota.

Sofyandi Herman. 2013. Pengertian pelatihan. https://www.google.com/search?q=pengertian+pelatihan+menurut+yusuf+2015. ( diakses pada tanggal 20 Februari 2021).

Undang - Undang Nomor 9 Tahun 2010 Tentang Keprotokolan.

Undang-Undang Republik Indonesia Nomor 5 Tahun 2014 Tentang Aparatur Sipil Negara.

Wiratna. V, Sujarweni. 2014. Metodologi Penelitian. Yogyakarta: Pustakabarrupress.

Yusuf. 2015. Pengertian pelatihan.

https://www.google.com/search?q=pengertian+pelatihan+menurut+yusuf+2015. ( diakses pada tanggal 20 Februari 2021) 